\title{
Characterization of Subpopulations (Clones and Subclones) of the 21 SF Strain of Trypanosoma cruzi after Long Lasting Maintenance in the Laboratory
}

\begin{abstract}
Rozalia MF Campos, Sonia G Andrade ${ }^{+}$
Centro de Pesquisas Gonçalo Moniz - FIOCRUZ, Rua Valdemar Falcão 121, 40295-001 Salvador, BA, Brasil

Several studies have shown a clonal structure of Trypanosoma cruzi and its possible correlation with the behavioral heterogeneity of the parasite strains. In the present study, the 21 SF strain, that have been maintained in laboratory by successive passages in mice, for more than 15 years, showing a stability of biological and isoenzymic characteristics has been cloned, with the objective of establishing the characters of its clones and subclones. With the technique of isolation of a single parasite from the blood of infected mice, 5 clones and 14 subclones have been obtained. After four passages into mice, inoculum of $10^{5}$ was obtained for each clone and subclone and inoculated into mice weighing 10 to 12 g. These were used for the study of the biological behavior of the clones: evolution of parasitemia, morphology of blood forms and host mortality. For isoenzymic characterization, the clones and subclones were analyzed for ALAT, ASAT, GPI and PGM enzymes. Results have shown that the 5 clones and the 14 subclones disclosed a biological behavior similar to the parental strain, with minor variability of the parasitemic profiles and also the same isoenzymic patterns. These results confirm the stability of the 21 $S F$ strain and indicate a clonal homogeneity of its populations. This is compatible with the hypothesis that the $\mathrm{T}$. cruzi strains represent an equilibrium of either homogenous or heterogeneous populations.
\end{abstract}

Keywords : Trypanosoma cruzi - strain - clones - biological characterization - zymodeme

Trypanosoma cruzi, the etiologic agent of Chagas disease, is found in nature as different populations parasitizing humans, domestic animals, silvatic vertebrates or triatomines. Studies on $T$. cruzi strains have disclosed intraspecific behavioral heterogeneity identified by several parameters (Andrade 1974, 1985). Clonal structure has been proposed to explain these differences (Tibayrenc et al. 1986). With the objective of clarifying behavioral differences between $T$. cruzi strains, biological and biochemical studies of parasite clones have been performed and results obtained suggest the occurrence of subpopulations in one same strain (Engel et al. 1982, Morel et al. 1986, Araújo \& Chiari 1988).

The equilibrium of these populations in one strain could be responsible for the maintenance of its biological behavior although some views on the contrary have suggested changes of behavior due to local or host conditions (Araujo \& Chiari 1988, Carneiro et al. 1990). The preservation of biological and biochemical characters of several strains after different laboratorial procedures as

${ }^{+}$Corresponding author. Fax: +55-71-359.4320

Received 19 April 1996

Accepted 21 August 1996 cryopreservation (Castro Silva et al. 1988), passages into different species of triatomine (Magalhães et al. 1985, Magalhães \& Andrade 1991), an the effect of chemotherapy (Castro Silva et al. 1989, Marretto \& Andrade 1994), has been observed. In the present study, the 21 SF strain, that has been maintained in laboratory by successive passages in mice for more than 15 years with stable biological and isoenzymic patterns has been used. This strain was cloned and subcloned with the objective of establishing the biological and biochemical behavior of its subpopulations.

\section{MATERIALS AND METHODS}

The $21 \mathrm{SF}$ strain of $T$. cruzi, previously described as Type II by Rocha Filho (1979) according to Andrade's classification (1974), was used in the present study. Biochemically this strain has been classified by Andrade et al. (1983) as zymodeme 2 - Z2 (Miles et al. 1980). It has been isolated from a patient during the acute phase of disease, from São Felipe, State of Bahia and maintained in the laboratory by successive passages into mice. Cloning was performed by isolating one single parasite from peripheral mouse blood. Citrated blood collected from infected mice was submitted to centrifugation in a refrigerated centrifuge at $900 \mathrm{~g}$, for separation of the erythrocytes and leukocytes; the supernatant was examined in 
Neubauer chamber for evaluation of parasites concentration. Dilution was performed with PBS and drops of $1 \mu 1$ were distributed in the wells of titration plaques and examined with an inverted microscope for isolation of one single parasite according to Dvorak (1985). Each well with one trypomastigote was filled with PBS. The contents was aspirated with $1 \mathrm{ml}$ syringe and inoculated intraperitoneally into one suckling mice (5 to 6 days old). Twelve to 14 days after inoculation parasitemia was evaluated and from each positive animal, representing one clone, inoculum was individually obtained and inoculated into suckling mice. Five clones were obtained and designated as $\mathrm{C} 1, \mathrm{C} 2, \mathrm{C} 3, \mathrm{C} 4$ and $\mathrm{C} 5$. For each clone four passages were performed in the 14th day after inoculation; in the fifth passage one group of mice weighing from 10 to $12 \mathrm{~g}$ was infected and studied to establish the biological behavior and isoenzymic characterization of the clone.

Subcloning of each clone was performed with the objective of studying a second generation. Blood was collected from one mouse for each clone group and, using the same methodology above, 14 subclones were obtained and designated as R1, $\mathrm{R} 2$, etc., preceeded by clone identification.

Clones and subclones were characterized according to biological and biochemical behavior. For biological characterization, 20 mice weighing from 10 to $12 \mathrm{~g}$ were infected with trypomastigotes from each clone and subclone, in the 4th passage in mice. Inocula were of $10^{5}$ blood forms. Parasitaemia was evaluated from the 7 th to the 21 st day of infection by microscopic examination in $5 \mu \mathrm{l}$ of tail blood; percentages of slender and broad forms were established by counting the parasites in Giemsa stained blood smears, in the 7th, 10th and 14th days after infection. Cumulative mortality was evaluated during 30 days.

Isoenzymic analysis was performed in culture forms obtained for each clone and subclone, by haemoculture in Warren medium. Parasites were washed with KRT buffer solution (Romanha et al. 1979) and enzymic extracts were prepared according to Godfrey and Kilgour (1976) and stored into liquid Nitrogen as " pearls" (Miles et al. 1977). The following isoenzymes were tested: alanine aminotransferase (ALAT) - E.C.2.6.1.2; aspartate aminotransferase (ASAT)-E.C.2.6.1.1.; glucosephosphate isomerase (GPI) - E.C.5.3.1.9.; phosphoglucomutase (PGM) - E.C.2.7.5.1. Electrophoresis was performed according to Miles et al. (1980).

\section{RESULTS}

Biological behaviour - All the clones and subclones determined parasitemic profiles charac- teristics for Type II strains and similar to the parental strain (21 SF), in the infected mice. Parasitemic peaks were irregular, between 12 and 20 days after infection (Fig. 1a, c, d); the clone C5 determined the lowest levels and the latest peak (Fig. 1a) of parasitemia. However the subclones of this clone (C5) reproduced the same profile of the other clones of the 21 SF strain (Fig. 1b).

The morphological characterization have shown the predominance of slender forms at the 7 th day of infection and of broad forms in the 10th and 14th days, for the 21SF strain and all its clones and subclones (Figs 2,3).

Mortality rates were variable, the highest percentage occurring between the 14th and 19th days after infection.

The biochemical analysis for the enzymes ALAT, ASAT, PGM and GPI of all clones and subclones have shown the eletrophoretic patterns of Z2, similar to the parental strain (Figs 4,5).

\section{DISCUSSION}

Strains of $T$. cruzi maintained in laboratory for long periods of time either by serial passages in mice (Brener et al. 1974) or after cryopreservation (Castro Silva et al. 1988), have preserved their biological and biochemical characteristics. This fact points to a stable equilibrium or homogeneity of their subpopulations. The 21SF strain, characterized in the Type II, zymodeme 2, has maintained its characteristics during more than 15 years of serial passages in mice and has been used as a prototype of Z2 in the electrophoresis for zymodeme characterization of several strains. In the present study, this strain has been chosen to be investigated in respect to its clonal constitution since the possibility of identification of clones with different characteristics could not be discharged. The results here obtained showed that the clones and subclones of the 21SF strain disclosed similar behavior as the parental strain regarding the biological patterns and isoenzyme profiles. Considering the parasitemic profiles isolately, slight differences occurred, predictable for this type of strain, as previously shown (Andrade 1974). Interesting to observe that even the clone 5 with a delayed parasitemic peak at 21 days produced subclones that showed parasitemias with the same variations as the observed in the parental strain and its clones.

The clonal structure for T. cruzi strains has been established by Tibayrenc et al. $(1985,1986)$ based on an heterogeneity of isozymic profiles and variations from the zymodemes patterns established by Miles et al. (1980). However it has been admitted that a limited number of "principal" clones could be circulating into different geographical areas (Tibayrenc \& Brenière 1988). Considering this 
A

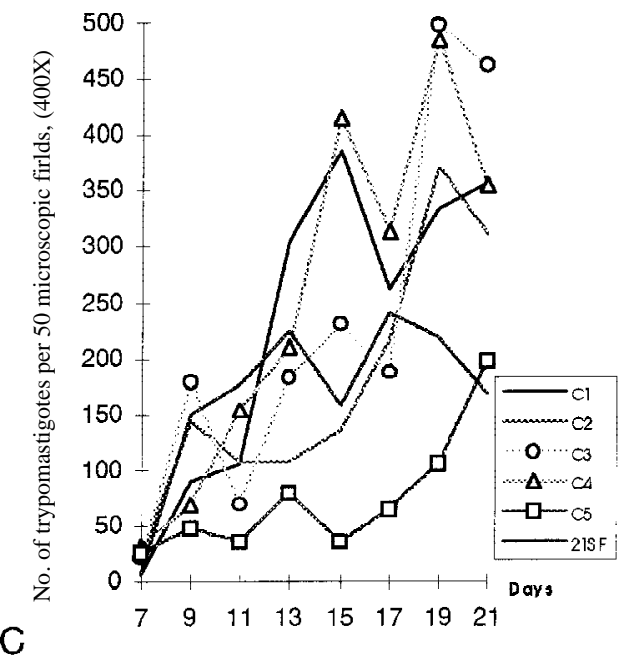

B

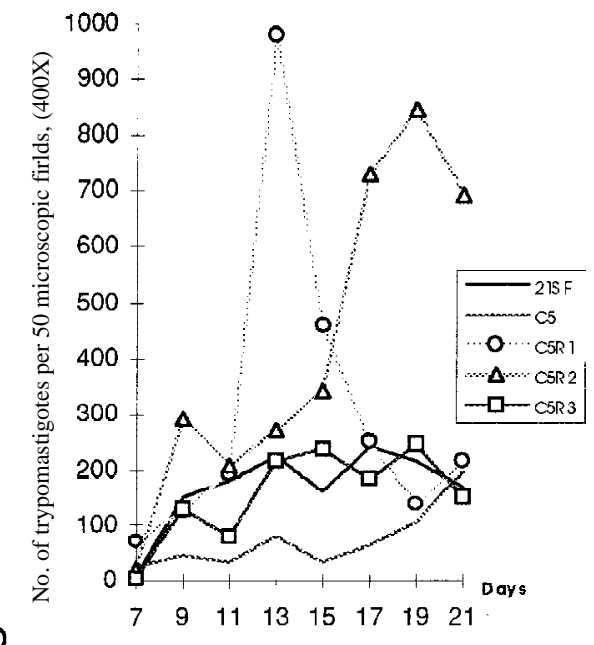

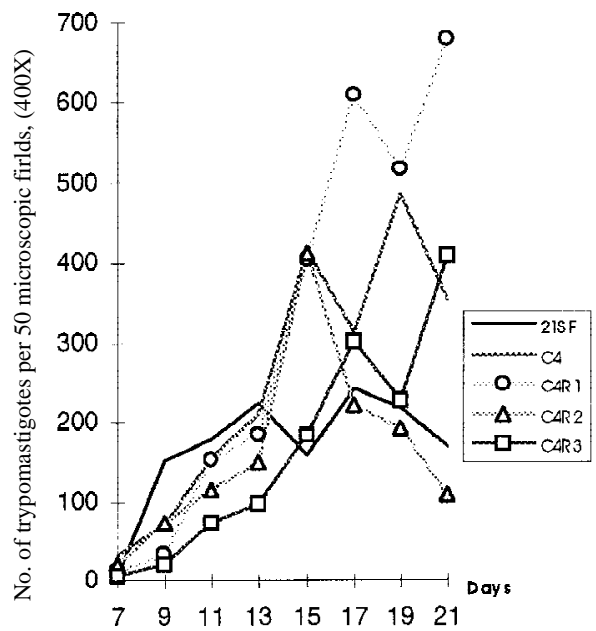

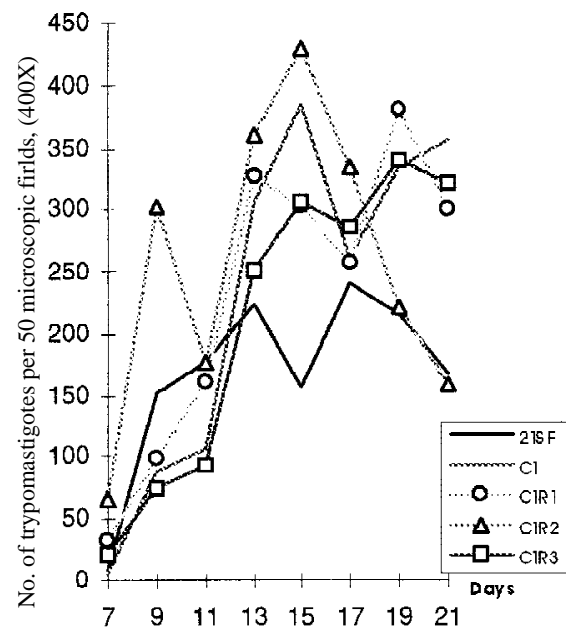

Fig. 1: parasitemia in mice infected with the $21 \mathrm{SF}$ strain and derived clones and subclones. A: parasitemic peaks of the 21SF strain and clones C1, C2, C3, C4 are irregular and occurred between 12 and 20 days; the clone C5 showed a delayed peak at 21 days. B: subclones of the $\mathrm{C} 5$ clone reproduce the irregular parasitemic peaks between 12 and 20 days with the same variations in their levels, as observed in the parental strain an its clones. C, D: the parental strain and clones $\mathrm{C} 4$ and $\mathrm{C} 1$ with the respective subclones, showing the parasitemic pattern of Type II strains.

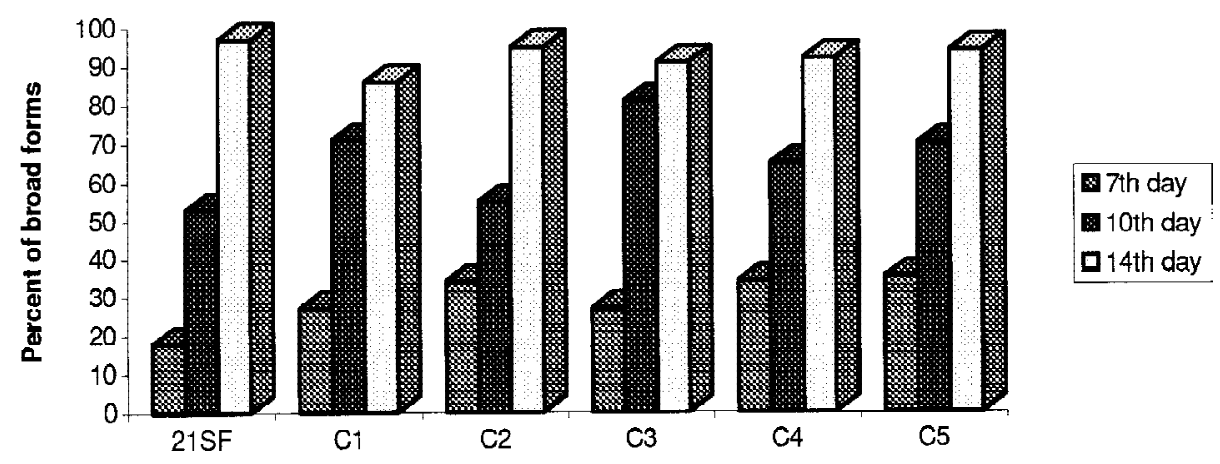

Fig. 2: percentages of broad forms of Trypanosoma cruzi in the peripheral blood of mice infected with the 21SF strain and five derived clones, showing the increasing number of broad forms from the 7th to the 14th day of infection in all groups. 


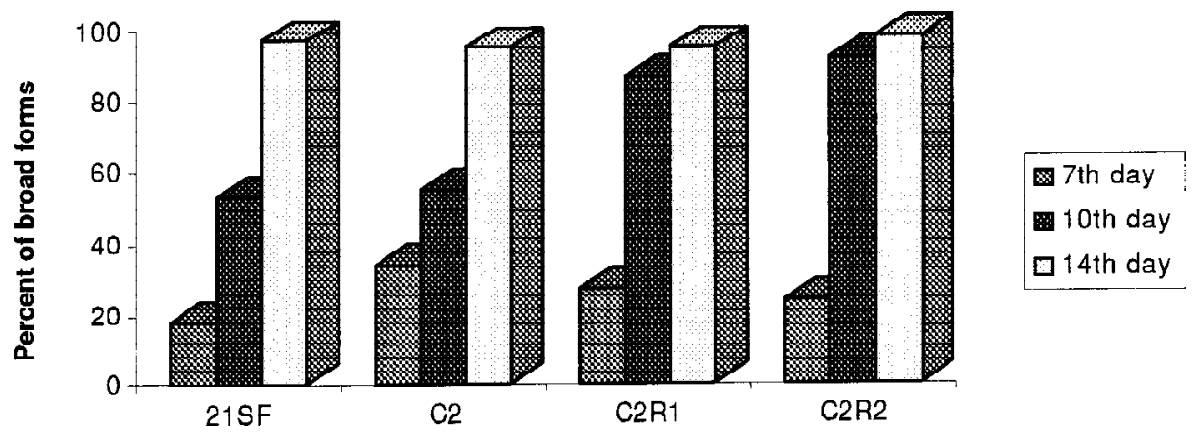

Fig. 3: morphological evaluation of the blood forms of the 21SF strain in comparison with the $\mathrm{C} 2$ clone and its subclones: the percentages of broad forms increase from the 7th to the 14th day of infection in all groups.
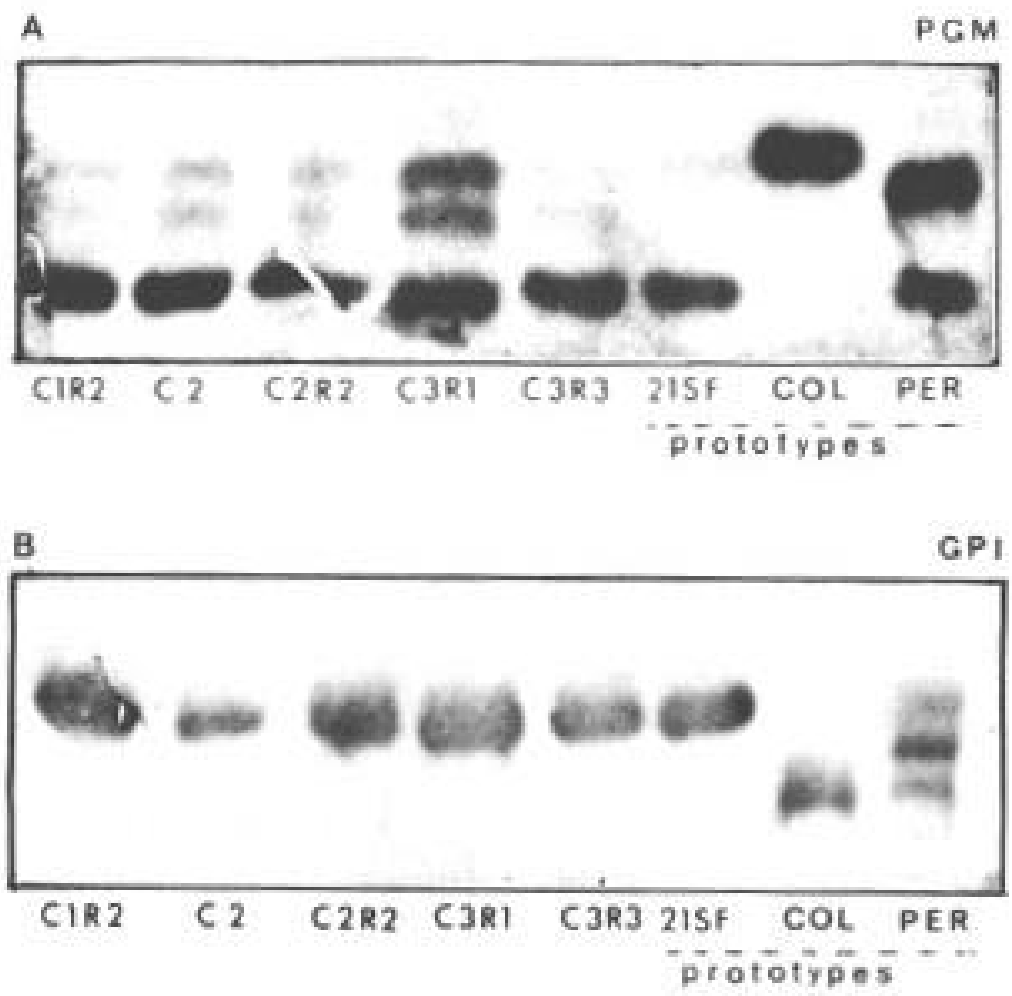

Fig. 4 A, B: electrophoretic patterns of isoenzymes PGM and GPI of clone C2, subclones C1R2, C2R2, C3R1, C3R3 in comparison to the parental strain (21SF), prototype of Type II (Z2) and with the Peruvian and Colombian strains, prototypes respectively of Type I (Z2b) and Type III (Z1) strains.

hypothesis, the homogeneity here disclosed for the clones and subclones of the $21 \mathrm{SF}$ strain, could represent the presence of a "principal" clone, corresponding to Type II, zymodeme 2 strains. This type of strain is predominant in the Recôncavo Bahiano (Andrade 1974) and other areas of Brazil, disclosing an ubiquitary distribution (Andrade \& Magalhães 1996). The clonal structure of T. cruzi, without recombinations, as proposed by Tibayrenc et al. (1981, 1986), can be seen in the electrophoresis of PGM (enzyme with tri-allelic locus), repre- sented as a heterozygous profile in all the clones and subclones. The strains of T. cruzi are not necessarily homogeneous populations and different clones can be disclosed by studies on their antigenic composition (Brenière et al. 1991), virulence (Postan et al. 1983), isoenzymic patterns (Goldberg \& Pereira 1983, Montamat et al. 1992), or kDNA patterns (Morel et al. 1980). More recently new approachs have been used with the same objective as the random amplified DNA (RAPD), suggesting the possibility of genetic exchange in $T$. 
A

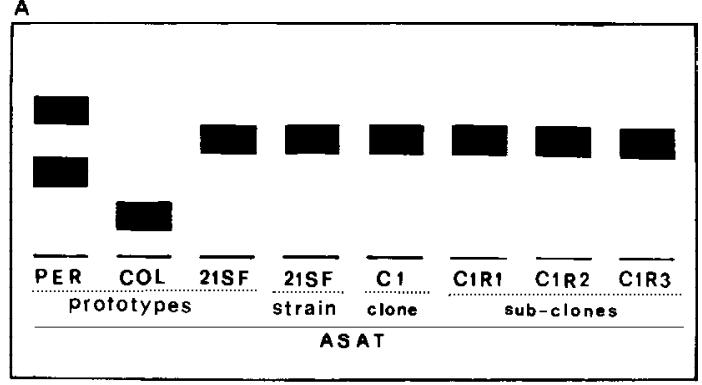

B

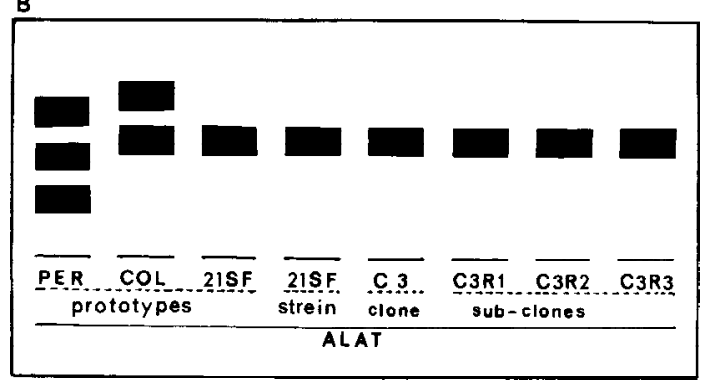

Fig. 5 A: ASAT isoenzymic pattern of the 21SF strain in comparison to clone $\mathrm{C} 1$ and its subclones $\mathrm{C} 1 \mathrm{R} 1, \mathrm{C} 1 \mathrm{R} 2, \mathrm{C} 1 \mathrm{R} 3$ and the prototypes Peruvian and Colombian. B: ALAT isoenzymic profiles of the clone $\mathrm{C} 3$ and subclones C3R1, C3R2, C3R3, in comparison to the parental strain (21SF) Type II and the prototypes of Type I (Per) and Type III (Col).

cruzi (Carrasco et al. 1996). As registered by McDaniel and Dvorak (1993) clones with the same isoenzymic and schizodeme profiles, can differ in their DNA content. In the present study, the biological and isozymic homogeneity of the 5 clones and 14 subclones of the 21 SF strain seem to indicate that this T. cruzi strain is composed predominantly by populations that are similar due to their phenotypic characteristics. This does not preclude that genomic characterization, by the analysis of the kDNA minicircles and maxicircles or the nuclear DNA could reveal new insights on the composition of the clones and subclones in comparison with the parental strain. These will be the future steps of the present investigation.

The histopathological studies with clinicopathological correlations points to the importance of the biological behaviour of T. cruzi strains. This seems most useful for the investigations on the different clinical features presented by Chagas' disease in different geographical areas, as previously discussed (Andrade \& Magalhães 1996). The stability of biological strain behaviour is a further argument of its potential utility for practical applications.

\section{AKNOWLEDGEMENT}

To CMG Santiago for technical help in the obtainance of the clones and to Dinalva França for the development of the axenic cultures.

\section{REFERENCES}

Andrade SG 1974. Caracterização de cepas do Trypanosoma cruzi isoladas no Recôncavo Baiano (Contribuição ao estudo da patologia geral da doença de Chagas em nosso meio). Rev Pat Trop 3: 65-121.

Andrade SG 1985. Morphological and behavioral characterization of Trypanosoma cruzi strains. Rev Soc Bras Med Trop 18 (Suppl): 39-46.

Andrade SG, Magalhães JB 1996. Trypanosoma cruzi strains: ubiquitary distribution in different geographical areas with correlations between biodemes, zimodemes and pathology of experimental Chagas disease. Rev Soc Bras Med Trop (in press).

Andrade V, Brodskyn C, Andrade SG 1983. Correlation between isoenzyme patterns and biological behaviour of different strains of Trypanosoma cruzi. Trans R SocTrop Med Hyg 76: 796-799.

Araujo MS, Chiari E 1988. Caracterização biológica de clones das cepas Y, CL e MR deTrypanosoma cruzi em camundongos $\mathrm{C} 3 \mathrm{H}$ isogênicos. Mem Inst Oswaldo Cruz 83: 175-181.

Brener Z, Chiari E, Alvarenga NJ 1974. Observations of Trypanosoma cruzi strain maintained over an 8year period in experimentally inoculated mice. Rev Inst Med Trop São Paulo 16: 39-46.

Brenière SF, Araniki I, LeRay D, Tibayrenc M 1991 L'analyse SDS-PAGE des protéines et antigènes de surface révèle une forte hétérogénéité chez les clones naturels de Trypanosoma cruzi, corrélée à la variabilité isoenzymatique. CR Acad Sci Paris Série III 312: 449-454.

Carneiro M, Chiari E, Gonçalves AM, Pereira AAS, Morel CM, Romanha AJ 1990. Changes in the isoenzyme and kinetoplast DNA patterns of Trypanosoma cruzi strains induced by maintenance in mice. Acta Trop 47: 35-45.

Carrasco HJ, Frame IA, Valente SA, Miles MA 1996. Genetic exchange as a possible source of genomic diversity in sylvatic populations of Trypanosoma cruzi . Am J Trop Med Hyg 54: 418-424.

Castro Silva R, Santiago CMG, Andrade SG 1988. Estudo da estabilidade dos caracteres isoenzimáticos de cepas do Trypanosoma cruzi em extratos enzimáticos estocados em nitrogênio líquido por período prolongado. Mem Inst Oswaldo Cruz 83 (Supl. I): 82.

Castro Silva R, Santiago CMG, Pontes AL, Andrade SG 1989. Padrão isoenzimático da cepa Y do Trypanosoma cruzi após quimioterapia específica. Mem Inst Oswaldo Cruz 84: 81-86.

Dvorak JA 1985. Single cell isolates of Trypanosoma cruzi: How and why? Rev Soc Bras Med Trop 18 (Suppl.): 29-38.

Engel JC, Dvorak JA, Segura EL, Crane JSt M 1982. Trypanosoma cruzi: biological characterization of 19 clones derived from two chagasic patients. I. 
Growth kinetics in liquid medium. J Protozool 29: 555-560.

Godfrey DG, Kilgour V 1976. Enzyme electrophoresis in characterizing the causative organism of gambian trypanosomiasis. Trans $R$ Soc Trop Med Hyg 3: 219-224.

Goldberg SS, Pereira SAA 1983. Enzyme variation among clones of Trypanosoma cruzi. J Parasitol 69: 91-96.

McDaniel JP, Dvorak JA 1993. Identification, isolation and characterization of naturally occuring Trypanosoma cruzi variants. Mol Biochem Parasitol 57: 213-222.

Magalhães JB, Andrade SG 1991. Estudo do comportamento de cepas do Trypanosoma cruzi após passagens em diferentes espécies de triatomíneos. Rev Soc Bras Med Trop 24: 209-216.

Magalhães JB, Pontes AL, Andrade SG 1985. Comportamento das cepas Y e Peruana do Trypanosoma cruzi no camundongo, após passagem em diferentes meios. Mem Inst Oswaldo Cruz 80: 41-50.

Marretto JPM, Andrade SG 1994. Biochemical behavior of Trypanosoma cruzi strains isolated from mice submitted to specific chemotherapy. Rev Soc Bras Med Trop 27: 209-215.

Miles MA, Toyé PJ, Oswald SC, Godfrey DG 1977. The identification by isoenzyme patterns of two distinct strain groups of Trypanosoma cruzi, circulating independently in a rural area of Brazil. Trans $R$ Soc Trop Med Hyg 71: 217-237.

Miles MA, Lanham SM, Souza AA, Povoa M 1980. Further enzymic characters of Trypanosoma cruzi in their evaluation for strain identification. Trans $R$ Soc Trop Med Hyg 74: 221-237.

Montamat EE, De Luca d' Oro G, Perret B, Rivas C 1992. Characterization of Trypanosoma cruzi from Argentina by electrophoretic zymograms. Acta Tropica 50: $125-133$.
Morel C, Chiari E, Camargo EP, Mattei DM, Romanha AJ, Simpson L 1980. Strains and clones of Trypanosoma cruzi can be caracterized by patterns of restriction endonuclease products of kinetoplast DNA minicircles. Proc Natl Acad Sci 77: 6810-6814.

Morel CM, Deane MP, Gonçalves AM 1986. The complexity of Trypanosoma cruzi populations revealed by schizodeme analysis. Parasitol Today 2: 4-8.

Postan M, Dvorak JA, McDaniel JP 1983. Studies of Trypanosoma cruzi clones in inbred mice I - A comparison of course of infections of $\mathrm{C} 3 \mathrm{H} / \mathrm{HEN}$ mice with two clones isolated on a common source. $\mathrm{Am} \mathrm{J}$ Trop Med Hyg 32: 497-506.

Rocha Filho FD 1979. Estudo comparativo de cepas do T. cruzi de diferentes procedências. Aspectos antigênicos, morfológicos e histopatológicos. Thesis. Universidade Federal da Bahia, 85 pp.

Romanha AJ, Silva Pereira AA, Chiari E, Kilgour V 1979. Isoenzyme patterns of cultured Trypanosoma cruzi changes after prolonged subculture. Comp Biochem Physiol 62: 139-142.

Tibayrenc M, Brenière SF 1988. Trypanosoma cruzi: major clones rather than principal zimodemes. $\mathrm{Mem}$ Inst Oswaldo Cruz, 83: (Suppl. I): 249-255.

Tibayrenc M, Brenière F, Barnabe C, Lemesre JL, Echaclar L, Desjeux P 1985. Isozymic variability of Trypanosoma cruzi: biological and epidemiological significance. Ann Soc belge Méd Trop 65 (Suppl. 1): 59-61.

Tibayrenc M, Cariou ML, Solignac M, Carlier Y, Grassé PP 1981. Arguments génétiques contre l'existence d'une sexualité actuelle chez Trypanosoma cruzi. Implications taxinomiques. C R Acad Sci Paris Serie III 293: 207-209.

Tibayrenc M, Ward P, Moya A, Ayala FJ 1986. Natural populations of Trypanosoma cruzi, the agent of Chagas disease, have a complex multiclonal structure. Proc Natl Acad Sci 83: 115-119. 